\title{
Effects of Nickel Chloride on Histopathological Lesions and Oxidative Damage in the Thymus
}

\author{
Kun Tang1, Jian Li' ${ }^{1}$, Shuang Yin'1, Hongrui Guo' ${ }^{1}$, Jie Deng1, Hengmin Cui ${ }^{1,2 *}$ \\ ${ }^{1}$ Key Laboratory of Animal Diseases and Environmental Hazards of Sichuan Province, Ya'an, China \\ ${ }^{2}$ College of Veterinary Medicine, Sichuan Agricultural University, Ya'an, China \\ Email: ${ }^{*}$ cui580420@sicau.edu.cn, ${ }^{*}$ cuihengmin2008@sina.com
}

Received 5 October 2014; revised 21 November 2014; accepted 5 December 2014

Copyright $(2014$ by authors and Scientific Research Publishing Inc.

This work is licensed under the Creative Commons Attribution International License (CC BY).

http://creativecommons.org/licenses/by/4.0/

(c) (i) Open Access

\begin{abstract}
The purpose of this study was to observe the histopathological lesions and oxidative damage induced by dietary nickel chloride $\left(\mathrm{NiCl}_{2}\right)$ in the thymus. A total of 280 one-day-old avian broilers were divided into four groups and fed on a corn-soybean basal diet as the control diet or the same basal diet supplemented with 300,600 , and $900 \mathrm{mg} / \mathrm{kg}$ of $\mathrm{NiCl}_{2}$ for 42 days. In the $\mathrm{NiCl}_{2}$-treated groups, the broiler weight and thymic relative weight were significantly $(P<0.05$ or $P<0.01)$ decreased. Histopathologically, thymic corpuscles were increased and enlarged; the reticular cells were degenerate and necrotic, and lymphocytes were slightly decreased and loosely arranged in the medulla of thymus in the $600 \mathrm{mg} / \mathrm{kg}$ and $900 \mathrm{mg} / \mathrm{kg}$ groups. The activities of superoxide dismutase (SOD), catalase (CAT) and glutathione peroxidase (GSH-Px), and the ability to inhibit hydroxy radical and glutathione (GSH) content were significantly $(P<0.05$ or $P<0.01)$ lower in the $\mathrm{NiCl}_{2}$-treated groups than those in the control group, while MDA content was higher. The abovementioned results demonstrated that dietary $\mathrm{NiCl}_{2}$ in excess of $300 \mathrm{mg} / \mathrm{kg}$ could reduce the broiler weight and thymic relative weight, and cause histopathological lesions and oxidative damage in the thymus, which finally impaired the thymic function.
\end{abstract}

\section{Keywords}

Nickel Chloride, Histopathological Lesions, Oxidative Damage, Thymus, Broiler

\section{Introduction}

Nickel (Ni) is the 24th most abundant element in the earth's crust, comprising about 3\% of the composition of "Corresponding author.

How to cite this paper: Tang, K., Li, J., Yin, S., Guo, H.R., Deng, J. and Cui, H.M. (2014) Effects of Nickel Chloride on Histopathological Lesions and Oxidative Damage in the Thymus. Health, 6, 2875-2882. 
the earth [1], and used in a wide variety of industrial and consumer applications [2]. At the same time, it is known to be an essential element for animals [3] [4]. Anke et al. [5] reported an absolute requirement for nickel in the ruminants (sheep, goat, and so on). Ni deficiency inhibits growth, reduces reproductive rate, and alters glucose and lipid metabolism, which are associated with anemia, hemoglobin reduction, alternations of metal ion contents, and reduced activity of several enzymes in animals [6]. However, Ni or Ni compounds can enter the food chain and may be toxic to living organisms. Ni gets into human and animals mainly through inhalation, drinking water and food, and food is the most important among these pathways [7]. The previous studies have shown that long-term exposure to $\mathrm{Ni}$ can also be toxic to the upper respiratory tract, skin, kidney, immune system, embryo, and breeding system [8] [9]. Even short-term exposure to Ni can significantly influence the cardiovascular system [10] [11]. Ni exposure causes formation of free radicals in various tissues in both human and animals, and enhances lipid peroxidation [12]. Thus, the toxic effects of $\mathrm{Ni}$ and $\mathrm{Ni}$ compounds have been major environmental health problems.

It had been reported that $\mathrm{Ni}$ can enhance lipid peroxidation (LPO) and cause cellular damage and reduced glutathione (GSH) contents, and catalase (CAT) and glutathione peroxidase (GSH-Px) activities in the liver and kidney of rats [13] [14]. $\mathrm{NiCl}_{2}$-induced human lymphocyte toxicity may be mediated by oxygen radical intermediates [15]. Our previous studies have also shown that dietary $\mathrm{NiCl}_{2}$ causes intestinal and splenic oxidative damage [12] [16]. However, very limited data are available on the oxidative damage induced by dietary $\mathrm{NiCl}_{2}$ in the thymus in human beings and animals. Also, there are no reports about effects of $\mathrm{NiCl}_{2}$ on thymic morphology in human and animals at present. In the present research, the experiment was conducted to examine the effects of dietary $\mathrm{NiCl}_{2}$ on thymus, induced clinical observation, histological lesions, relative weight and oxidative stress parameters (the activities of SOD, CAT, GSH-Px, and ability to inhibit hydroxyl radical, and GSH and MDA contents), which provided helpful materials for the same or similar studies in both human and other animals in the future.

\section{Materials and Methods}

\section{Chickens and diets}

Two hundred eighty one-day-old healthy broilers were randomly divided into four equal groups of 70 . The broilers were housed in separate cages with electrically heated units and were provided with water and the control or experimental diets ad libitum for 42 days.

Our experiments involving the use of broilers and all experimental procedures involving animals were approved by Sichuan Agricultural University Animal Care and Use Committee.

A corn-soybean basal diet formulated by the National Research Council (1994) [17] was the control diet. $\mathrm{NiCl}_{2} \cdot 6 \mathrm{H}_{2} \mathrm{O}$ (Cheng Du Kelong Chemical Co., Ltd., Chengdu, China) was mixed into the corn-soybean basal diet to produce experimental diets with 300,600 , and $900 \mathrm{mg} / \mathrm{kg}$ of $\mathrm{NiCl}_{2}$, respectively.

\section{Clinical signs and relative weight of thymus}

Clinical signs were observed and recorded everyday. At 7, 14, 21, 28, 35 and 42 days of age during the experiment, five broilers in each group were euthanized and necropsied after their body weight were weighed. Thymus was dissected from each broiler and weighed after dissecting connective tissue around the organ, and the macroscopic changes of thymus were observed and recorded. Related weight of thymus was calculated by the following formula:

Related weight $=$ organ weight $(\mathrm{g}) /$ body weight $(\mathrm{kg})$

\section{Pathological observation}

After weighed, thymuses were fixed in $4 \%$ paraformaldehyde and routinely processed in paraffin. Thin sections $(5 \mu \mathrm{m})$ of each tissue were sliced from each block and mounted on glass. Slices were stained with hematoxylin and eosin (H\&E) and were examined on an Olympus light microscope.

\section{Detection of oxidative damage parameters in the thymus}

At 14, 28 and 42 days of age, after five broilers in each group were humanely killed, thymuses were immediately removed and chilled to $0^{\circ} \mathrm{C}$ in $0.85 \% \mathrm{NaCl}$, and then dried, weighed and homogenized in 9 vol of icecold $0.85 \% \mathrm{NaCl}$ in a chilled homogenizer and centrifuged at $3500 \times \mathrm{g}$ at $4^{\circ} \mathrm{C}$ for $10 \mathrm{~min}$. Then the supernatant were collected. After determining the amount of total protein in the supernatant by the method of Bradford [18], the CAT, SOD and GSH-Px activities, and ability to inhibit hydroxyl radical, and MDA and GSH contents in the supernatant were detected by biochemical methods following the instruction of the reagent kits (CAT, A007; 
SOD, A001-1; GSH-Px, A005; abilities to inhibit hydroxy radical, A018; GSH, A006-1; MDA, A003-1; total protein, A045-2, purchased from Nanjing Jiancheng Bioengineering Institute of China, Nanjing, China). The absorbance was measured at 240, 550, 412, 550, 532, 420 and $590 \mathrm{~nm}$, respectively using a microtiter plate reader (Thermo, Varioskan Flash, USA).

\section{Statistical analysis}

The significance of difference between the control groups and the $\mathrm{NiCl}_{2}$-treated groups was analyzed by use of variance analysis, and the results are presented as means \pm standard deviation $(X \pm \mathrm{SD})$. The analysis was performed with the one-way analysis of variance (ANOVA) test of SPSS 16.0 for windows. A value of $P<0.05$ was considered significant.

\section{Results}

\section{Clinical observation}

From 14 to 42 days of age during the experiment, the feed intake of broilers in the $300 \mathrm{mg} / \mathrm{kg}, 600 \mathrm{mg} / \mathrm{kg}$, and $900 \mathrm{mg} / \mathrm{kg}$ groups began to decline when compared with that in the control group, except the $300 \mathrm{mg} / \mathrm{kg}$ group at 14 days of age. From 21 to 42 days of age during the experiment, broilers in the $300 \mathrm{mg} / \mathrm{kg}, 600 \mathrm{mg} / \mathrm{kg}$, and $900 \mathrm{mg} / \mathrm{kg}$ groups showed poor appetite, poor growth and depression. A few broilers showed polypnea. No death was found during the experiment. Change of broiler weight was shown in Figure 1.

\section{Change of thymic relative weight}

From 21 to 42 days of age during the experiment, the thymic relative weight of broilers were significantly decreased $(P<0.05$ or $P<0.01)$ in the $300 \mathrm{mg} / \mathrm{kg}, 600 \mathrm{mg} / \mathrm{kg}$, and $900 \mathrm{mg} / \mathrm{kg}$ groups in comparison with those in the control group. The results were shown in Figure 2.

\section{Pathological lesions}

There were no obvious lesions among $\mathrm{NiCl}_{2}$-treated groups at 7, 14, and 21 days of age when compared with the control group. From 21 to 42 days of age, the thymic corpuscles were increased and enlarged, the cells were degenerate and necrotic reticular, and lymphocytes were slightly decreased and loosely arranged in the medulla of thymus in the $600 \mathrm{mg} / \mathrm{kg}$ and $900 \mathrm{mg} / \mathrm{kg}$ groups (Figure 3).

Changes of oxidative damage parameters in the thymus

The CAT, SOD, and GSH-Px activities were significantly lower $(P<0.05$ or $P<0.01)$ in the $900 \mathrm{mg} / \mathrm{kg}$ group at 14 days of age, and in the $300 \mathrm{mg} / \mathrm{kg}, 600 \mathrm{mg} / \mathrm{kg}$, and $900 \mathrm{mg} / \mathrm{kg}$ groups from 28 to 42 days of age than those in the control group, except the SOD and GSH-Px activities in the $300 \mathrm{mg} / \mathrm{kg}$ group at 28 days of age. The ability to inhibit hydroxyl radical were significantly decreased $(P<0.05$ or $P<0.01)$ in the $600 \mathrm{mg} / \mathrm{kg}$ and 900 $\mathrm{mg} / \mathrm{kg}$ groups at 14 to 42 days of age when compared with those of the control group, except that in the 600 $\mathrm{mg} / \mathrm{kg}$ group at 14 days of age. The GSH contents were significantly lower $(P<0.05$ or $P<0.01)$ in the 900 $\mathrm{mg} / \mathrm{kg}$ group at 14 days of age, and in the $300 \mathrm{mg} / \mathrm{kg}, 600 \mathrm{mg} / \mathrm{kg}$, and $900 \mathrm{mg} / \mathrm{kg}$ groups at 28 to 42 days of age than those in the control group, except the GSH contents in the $300 \mathrm{mg} / \mathrm{kg}$ group at 28 days of age. The MDA contents were significantly higher $(P<0.05$ or $P<0.01)$ in the $300 \mathrm{mg} / \mathrm{kg}, 600 \mathrm{mg} / \mathrm{kg}$, and $900 \mathrm{mg} / \mathrm{kg}$ groups at 28 to 42 days of age than those in the control group, except the MDA contents in the $300 \mathrm{mg} / \mathrm{kg}$ group at 28 days of age. The results were shown in Figure 4.

\section{Discussion}

In the present study, the growth of the $\mathrm{NiCl}_{2}$-treated broilers was inhibited, and the above-mentioned clinical signs showed that dietary $\mathrm{NiCl}_{2}$ in excess of $300 \mathrm{mg} / \mathrm{kg}$ was toxic to broilers from 3-week-old, which was consistent with those described in broilers by Ling and Leach [19].

Thymus is the central immune organs. The situation of thymus development is usually judged by the thymic relative weight [20]. The relative weight of thymus in $\mathrm{NiCl}_{2}$-treated groups was lower than that in control group, which implied dietary $\mathrm{NiCl}_{2}$ in excess of $300 \mathrm{mg} / \mathrm{kg}$ inhibited the thymus growth, and could finally impair the function of thymus. Histopathologically, thymic corpuscles were increased and enlarged, the reticular cells were degenerate and necrotic, and lymphocytes were decreased and loosely arranged in the medulla of thymus in the $600 \mathrm{mg} / \mathrm{kg}$ and $900 \mathrm{mg} / \mathrm{kg}$ groups, implying that dietary $\mathrm{NiCl}_{2}$ in excess of $300 \mathrm{mg} / \mathrm{kg}$ could influence or/and impair thymic function and growth.

It is well known that there are close relationships between lesions and oxidative damage caused by $\mathrm{NiCl}_{2}$.

Living organisms possess several antioxidative agents (including enzymes such as SOD, GSH-Px, and CAT, 
— Control group $\square 300 \mathrm{mg} / \mathrm{kg}$ group $\square 600 \mathrm{mg} / \mathrm{kg}$ group $\square 900 \mathrm{mg} / \mathrm{kg}$ group

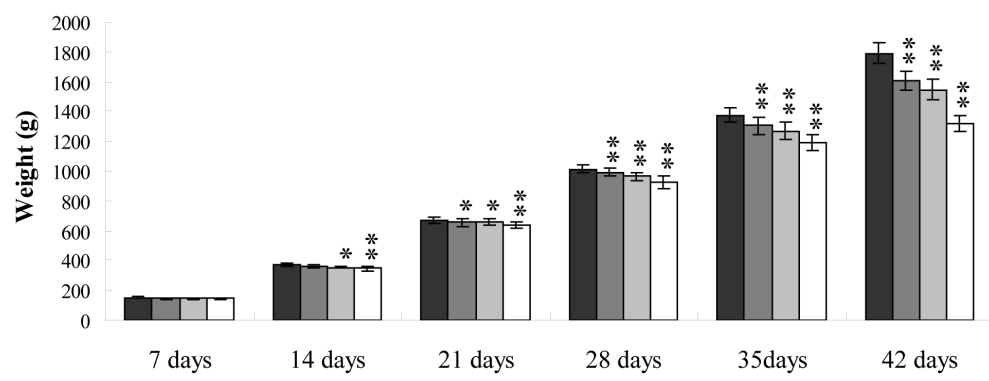

Data are presented with the mean \pm standard deviation $(n=5)$. ${ }^{*} P<0.05$, compared with the control group. ${ }^{* *} P<0.01$, compared with the control group.

Figure 1. Changes of broiler weight (g).

口 Control group $\square 300 \mathrm{mg} / \mathrm{kg}$ group $\square 600 \mathrm{mg} / \mathrm{kg}$ group $\square 900 \mathrm{mg} / \mathrm{kg}$ group

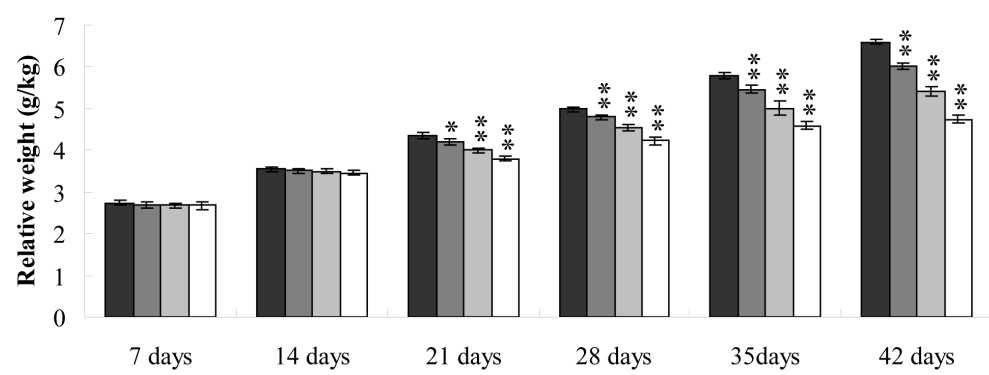

Data are presented with the mean \pm standard deviation $(n=5) .{ }^{*} P<0.05$, compared with the control group. ${ }^{* *} P<0.01$, compared with the control group.

Figure 2. Changes of relative weight in the thymus.

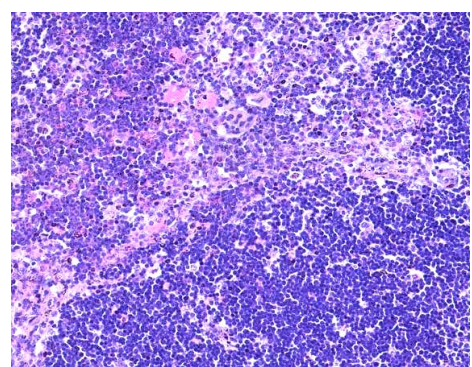

(a)

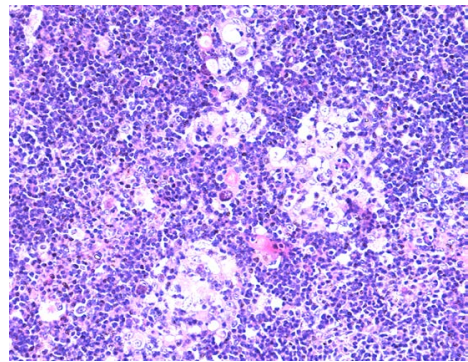

(c)

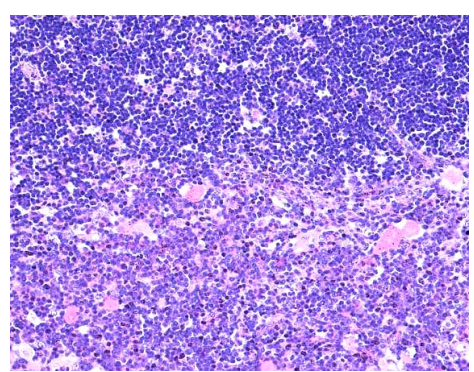

(b)

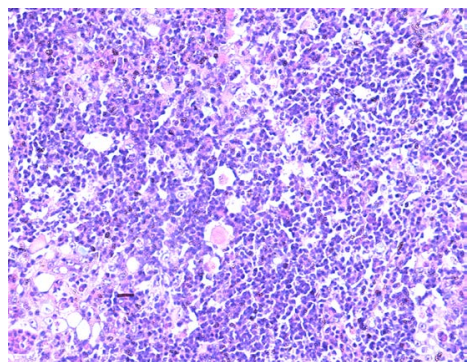

(d)

(a) Thymus in the control group; (b) Thymus in the $300 \mathrm{mg} / \mathrm{kg}$ group; (c) Thymus in the $600 \mathrm{mg} / \mathrm{kg}$ group. The thymic corpuscles are increased and enlarged, the reticular cells are degenerate and necrotic, and lymphocytes are slightly decreased and loosely arranged in the medulla; (d) Thymus in the $900 \mathrm{mg} / \mathrm{kg}$ group. The thymic corpuscles are increased and enlarged, the reticular cells are degenerate and necrotic, and lymphocytes are decreased and loosely arranged in the medulla. H.E $\times 400$.

Figure 3. Histopathological changes in the thymus at 42 days of age. 
$\square$ Control group
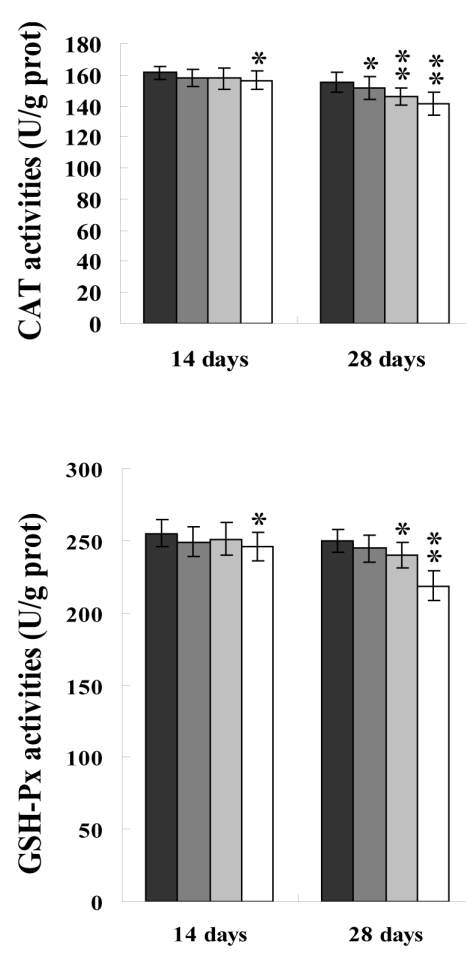

28 days
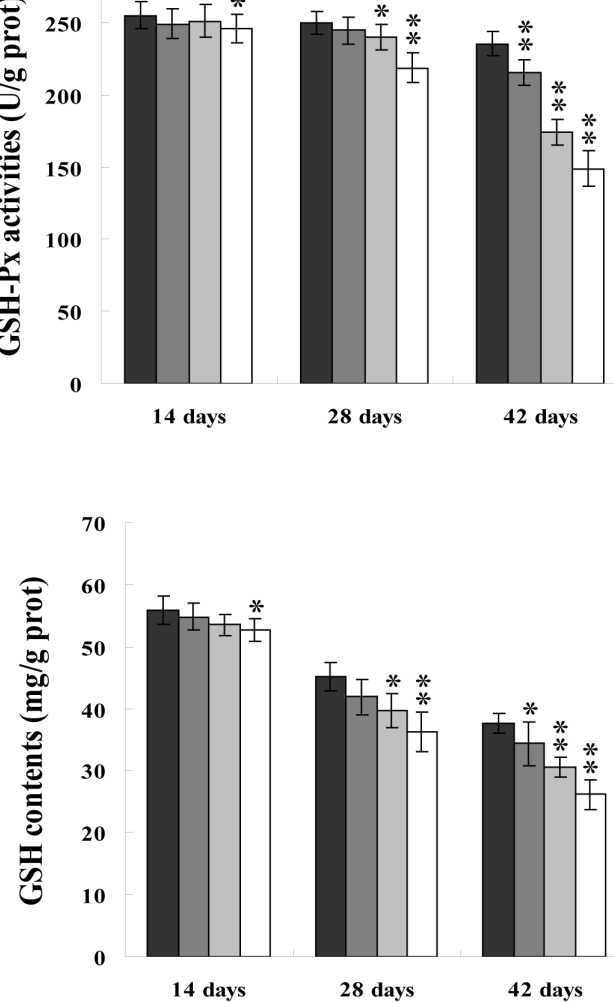

$\square 300 \mathrm{mg} / \mathrm{kg}$ group
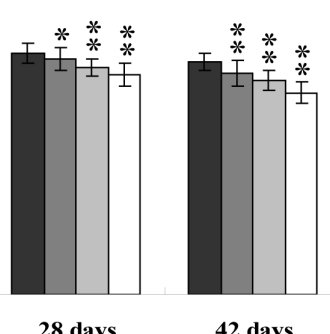

42 days $\square 600 \mathrm{mg} / \mathrm{kg}$ group

$\square 900 \mathrm{mg} / \mathrm{kg}$ group

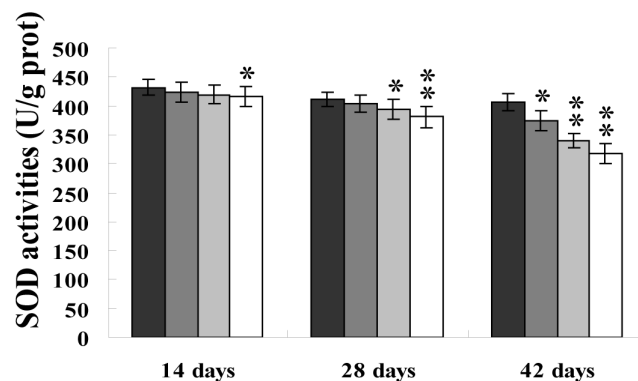

Data are presented with the mean \pm standard deviation $(\mathrm{n}=5) .{ }^{*} P<0.05$, compared with the control group. ${ }^{* *} P<0.01$, compared with the control group.

Figure 4. Changes of oxidative stress parameters in the thymus.

GSH, and the ability to inhibit hydroxyl radical, and nonenzymatic antioxidants such as extra calcium and vitamin E) and protect them against the harmful effect of oxidative stress [16] [21] [22]. These antioxidants inhibit overproduced free radicals (including ROS and $\mathrm{OH}$ ), which induces lipid peroxidation (LPO) [23]. It has been reported that Ni ion accumulation may be responsible for the generation of ROS and the enhancement of LPO [24]. LPO may be a contributing factor in Ni-induced tissue oxidative stress [25]. As the first line of cellular defence against oxidative damage, SOD and CAT play an important role in these enzymatic mechanisms [26]. SOD can break up ROS and repair cellular damage caused by ROS [16]. CAT is responsible for the breakdown of hydrogen peroxide $\left(\mathrm{H}_{2} \mathrm{O}_{2}\right)$ [27]. Our results showed that SOD and CAT were decreased in $\mathrm{NiCl}_{2}$-treated groups when compared with those in the control group, which demonstrated that free radicals species are accumulation in the thymus of $\mathrm{NiCl}_{2}$-treated groups, and reduction of the SOD and CAT activities enhances ROS production and $\mathrm{H}_{2} \mathrm{O}_{2}$ generation [28]. 
GSH is considered to be an important bio-marker in LPO and is important in maintaining the cellular redox status [29], and depletion of intracellular free radical scavengers such as GSH is one of Ni-caused oxidative stress mechanisms [30] [31]. GSH-Px activity depends on the balance between the levels of GSH and glutathione disulfide [32], and GSH-Px works in tandem with CAT to scavenge excess hydrogen peroxide and lipid peroxides in response to oxidative stress [33]. In the present study, we found the significantly reduced of GSHPx and CAT activities, and GSH contents in the $\mathrm{NiCl}_{2}$-treated groups in comparison with those in the control group, which was agree with previous studies [13] [14]. The hydroxyl radical is one of the major oxygen radicals, and causes oxidative stress and damages virtually all types of macromolecules: carbohydrates, nucleic acids, lipids and amino acids, and the scavenging peroxyl radicals for the protection of cellular structures includes endogenous antioxidants such as melatonin and glutathione [34]. In this study, the ability to inhibit hydroxyl radical was reduced, suggesting that more hydroxyl radicals were accumulating in the thymus.

The MDA levels elevated by free radicals are recognized as a good marker of increased LPO in tissues [35]. Besides, MDA inhibits various enzyme reactions and exerts mutagenicity and carcinogenicity by forming DNA adducts [36]. The MDA contents were increased in $\mathrm{NiCl}_{2}$-treated groups when compared with that in the control group in our study, which were similar to the findings by Rao et al. [37] and Lou et al. [38], implying that the thymus was undergoing the oxidative stress.

In our study, the activities of CAT, SOD, GSH-Px, and ability to inhibit hydroxyl radical and the GSH contents were decreased, while MDA contents were increased in the $\mathrm{NiCl}_{2}$-treated groups, demonstrating dietary $\mathrm{NiCl}_{2}$ in excess of $300 \mathrm{mg} / \mathrm{kg}$ in broiler chicks induced oxidative damage in the thymus.

\section{Conclusion}

Based on the results observed in the present study and the aforementioned discussion, it is concluded that dietary $\mathrm{NiCl}_{2}$ in excess of $300 \mathrm{mg} / \mathrm{kg}$ in broiler chicks is toxic to thymus by inducing oxidative damage, then causing lesions and reducing relative weight. Toxicity caused by $\mathrm{NiCl}_{2}$ likely has important effects on the thymic function. This study provided new evidences and an animal model to further understand the mechanism of the effects of $\mathrm{NiCl}_{2}$ on the thymic function.

\section{Acknowledgements}

The study was supported by the program for Changjiang scholars and innovative research team in university (IRT 0848) and the Shuangzhi Project of Sichuan Agricultural University (03570327).

\section{Conflict of Interest}

The authors declare no conflict of interest.

\section{References}

[1] Cempel, M. and Nikel, G. (2006) Nickel: A Review of Its Sources and Environmental Toxicology. Polish Journal of Environmental Studies, 15, 375-382.

[2] Grandjean, P. (1983) Human Exposure to Nickel. IARC Scientific Publications, 5, 469-485.

[3] Marzec, Z. (2004) Alimentary Chromium, Nickel, and Selenium Intake of Adults in Poland Estimated by Analysis and Calculations Using the Duplicate Portion Technique. Die Nahrung, 48, 47-52. http://dx.doi.org/10.1002/food.200300355

[4] Spears, J. (1984) Nickel as a "Newer Trace Element” in the Nutrition of Domestic Animals. Journal of Animal Science, 59, 823-835.

[5] Anke, M., Partschefeld, M., Grün, M. and Groppel, B. (1978) Nickel—Ein essentielles Spurenelement. Archives of Animal Nutrition, 28, 83-90.

[6] Samal, L. and Mishra, C. (2011) Significance of Nickel in Livestock Health and Production. International Journal for Agro Veterinary and Medical Sciences, 5, 349-361. http://dx.doi.org/10.5455/ijavms.20110331111304

[7] Haber, L., Erdreicht, L., Diamond, G., Maier, A., Ratney, R., Zhao, Q. and Dourson, M. (2000) Hazard Identification and Dose Response of Inhaled Nickel-Soluble Salts. Regulatory Toxicology and Pharmacology, 31, 210-230. http://dx.doi.org/10.1006/rtph.2000.1377

[8] Kasprzak, K.S., Sunderman Jr, F.W. and Salnikow, K. (2003) Nickel Carcinogenesis. Mutation Research: Fundamen- 
tal and Molecular Mechanisms, 533, 67-97. http://dx.doi.org/10.1016/j.mrfmmm.2003.08.021

[9] Haley, P.J., Bice, D.E., Muggenburg, B.A., Hann, F.F. and Benjamin, S.A. (1987) Immunopathologic Effects of Nickel Subsulfide on the Primate Pulmonary Immune System. Toxicology and Applied Pharmacology, 88, 1-12. http://dx.doi.org/10.1016/0041-008X(87)90264-X

[10] Donskoy, E., Donskoy, M., Forouhar, F., Gillies, C., Marzouk, A., Reid, M., Zaharia, O. and Sunderman, F. (1986) Hepatic Toxicity of Nickel Chloride in Rats. Annals of Clinical \& Laboratory Science, 16, 108-117.

[11] Doreswamy, K., Shrilatha, B. and Rajeshkumar, T. (2004) Nickel-Induced Oxidative Stress in Testis of Mice: Evidence of DNA Damage and Genotoxic Effects. Journal of Andrology, 25, 996-1003.

[12] Wu, B., Cui, H., Peng, X., Fang, J., Zuo, Z., Deng, J. and Huang, J. (2013) Dietary Nickel Chloride Induces Oxidative Intestinal Damage in Broilers. International Journal of Environmental Research and Public Health, 10, 2109-2119. http://dx.doi.org/10.3390/ijerph10062109

[13] Chakrabarti, S.K. and Bai, C. (1999) Role of Oxidative Stress in Nickel Chloride-Induced Cell Injury in Rat Renal Cortical Slices. Biochemical Pharmacology, 58, 1501-1510. http://dx.doi.org/10.1016/S0006-2952(99)00232-4

[14] Misra, M., Rodriguez, R.E. and Kasprzak, K.S. (1990) Nickel Induced Lipid Peroxidation in the Rat: Correlation with Nickel Effect on Antioxidant Defense Systems. Toxicology, 64, 1-17. http://dx.doi.org/10.1016/0300-483X(90)90095-X

[15] Chen, C.-Y., Wang, Y.-F., Lin, Y.-H. and Yen, S.-F. (2003) Nickel-Induced Oxidative Stress and Effect of Antioxidants in Human Lymphocytes. Archives of Toxicology, 77, 123-130.

[16] Huang, J., Cui, H., Peng, X., Fang, J., Zuo, Z., Deng, J. and Wu, B. (2013) The Association between Splenocyte Apoptosis and Alterations of Bax, Bcl-2 and Caspase-3 mRNA Expression, and Oxidative Stress Induced by Dietary Nickel Chloride in Broilers. International Journal of Environmental Research and Public Health, 10, 7310-7326. http://dx.doi.org/10.3390/ijerph10127310

[17] National Research Council (1994) Nutrient Requirements of Poultry. National Academy Press, Washington DC.

[18] Bradford, M.M. (1976) A Rapid and Sensitive Method for the Quantitation of Microgram Quantities of Protein Utilizing the Principle of Protein-Dye Binding. Analytical Biochemistry, 72, 248-254. http://dx.doi.org/10.1016/0003-2697(76)90527-3

[19] Ling, J. and Leach, R. (1979) Studies on Nickel Metabolism: Interaction with Other Mineral Elements. Poultry Science, 58, 591-596. http://dx.doi.org/10.3382/ps.0580591

[20] Chen, K., Shu, G., Peng, X., Fang, J., Cui, H., Chen, J., Wang, F., Chen, Z., Zuo, Z. and Deng, J. (2013) Protective Role of Sodium Selenite on Histopathological Lesions, Decreased T-Cell Subsets and Increased Apoptosis of Thymus in Broilers Intoxicated with Aflatoxin B1. Food and Chemical Toxicology, 59, 446-454. http://dx.doi.org/10.1016/j.fct.2013.06.032

[21] Chlubeka, D. (2003) Fluoride and Oxidative Stress. Fluoride, 36, 217-228.

[22] Maiti, R. and Ghosh, D. (2006) Management of Fluoride Induced Testicular Disorders by Calcium and Vitamin-E Co-Administration in the Albino Rat. Reproductive Toxicology, 22, 606-612. http://dx.doi.org/10.1016/j.reprotox.2006.05.001

[23] Paller, M.S., Hoidal, J. and Ferris, T.F. (1984) Oxygen Free Radicals in Ischemic Acute Renal Failure in the Rat. Journal of Clinical Investigation, 74, 1156-1164. http://dx.doi.org/10.1172/JCI111524

[24] Stohs, S. and Bagchi, D. (1995) Oxidative Mechanisms in the Toxicity of Metal Ions. Free Radical Biology and Medicine, 18, 321-336. http://dx.doi.org/10.1016/0891-5849(94)00159-H

[25] Chen, C.-Y., Sheu, J.-Y. and Lin, T.-H. (1999) Oxidative Effects of Nickel on Bone Marrow and Blood of Rats. Journal of Toxicology and Environmental Health Part A, 58, 475-483. http://dx.doi.org/10.1080/009841099157106

[26] Ferreccio, C., Psych, C.G., Stat, V.M., Gredis, G.M. and Sancha, A.M. (1998) Lung Cancer and Arsenic Exposure in Drinking Water: A Case-Control Study in Northern Chile. Cadernos de Saúde Pública, 14, S193-S198. http://dx.doi.org/10.1590/S0102-311X1998000700021

[27] Altıntaş, L., Eşsiz, D., Eraslan, G., İnce, S. and Arslanbaş, E. (2010) Prophylactic Effect of N-Acetylcysteine against Sodium Fluoride-Induced Blood Oxidative Stress in Mice. Food and Chemical Toxicology, 48, 2838-2841. http://dx.doi.org/10.1016/j.fct.2010.07.015

[28] Kubrak, O.I., Husak, V.V., Rovenko, B.M., Poigner, H., Mazepa, M.A., Kriews, M., Abele, D. and Lushchak, V.I. (2012) Tissue Specificity in Nickel Uptake and Induction of Oxidative Stress in Kidney and Spleen of Goldfish Carassius auratus, Exposed to Waterborne Nickel. Aquatic Toxicology, 118, 88-96. http://dx.doi.org/10.1016/j.aquatox.2012.03.016

[29] Streit, W.J. and Kincaid-Colton, C.A. (1995) The Brain’s Immune System. Scientific American, 273, 54-61. http://dx.doi.org/10.1038/scientificamerican1195-54

[30] Salnikow, K., Gao, M., Voitkun, V., Huang, X. and Costa, M. (1994) Altered Oxidative Stress Responses in Nickel- 
Resistant Mammalian Cells. Cancer Research, 54, 6407-6412.

[31] Boadi, W.Y., Harris, S., Anderson, J.B. and Adunyah, S.E. (2013) Lipid Peroxides and Glutathione Status in Human Progenitor Mononuclear (U937) Cells Following Exposure to Low Doses of Nickel and Copper. Drug and Chemical Toxicology, 36, 155-162. http://dx.doi.org/10.3109/01480545.2012.660947

[32] Łuczaj, W. and Skrzydlewska, E. (2004) Antioxidant Properties of Black Tea in Alcohol Intoxication. Food and Chemical Toxicology, 42, 2045-2051. http://dx.doi.org/10.1016/j.fct.2004.08.009

[33] Chen, L., Xi, S. and Cohen, D. (1995) Liver Antioxidant Defenses in Mice Fed Ethanol and the AIN-76A Diet. Alcohol, 12, 453-457. http://dx.doi.org/10.1016/0741-8329(95)00030-U

[34] Reiter, R.J., Melchiorri, D., Sewerynek, E., Poeggeler, B., Barlow-Walden, L., Chuang, J., Ortiz, G.G. and Acuña-Castroviejo, D. (1995) A Review of the Evidence Supporting Melatonin's Role as an Antioxidant. Journal of Pineal Research, 18, 1-11. http://dx.doi.org/10.1111/j.1600-079X.1995.tb00133.x

[35] Gaweł, S., Wardas, M., Niedworok, E. and Wardas, P. (2003) Malondialdehyde (MDA) as a Lipid Peroxidation Marker. Wiadomosci Lekarskie, 57, 453-455.

[36] Marnett, L.J. (1999) Lipid Peroxidation-DNA Damage by Malondialdehyde. Mutation Research-Fundamental and Molecular Mechanisms, 424, 83-95. http://dx.doi.org/10.1016/S0027-5107(99)00010-X

[37] Rao, M.V., Chawla, S.L. and Sharma, S.R. (2009) Protective Role of Vitamin E on Nickel and/or Chromium Induced Oxidative Stress in the Mouse Ovary. Food and Chemical Toxicology, 47, 1368-1371. http://dx.doi.org/10.1016/j.fct.2009.03.018

[38] Lou, J., Jin, L., Wu, N., Tan, Y., Song, Y., Gao, M., Liu, K., Zhang, X. and He, J. (2013) DNA Damage and Oxidative Stress in Human B Lymphoblastoid Cells after Combined Exposure to Hexavalent Chromium and Nickel Compounds. Food and Chemical Toxicology, 55, 533-540. http://dx.doi.org/10.1016/j.fct.2013.01.053 
Scientific Research Publishing (SCIRP) is one of the largest Open Access journal publishers. It is currently publishing more than 200 open access, online, peer-reviewed journals covering a wide range of academic disciplines. SCIRP serves the worldwide academic communities and contributes to the progress and application of science with its publication.

Other selected journals from SCIRP are listed as below. Submit your manuscript to us via either submit@scirp.org or Online Submission Portal.
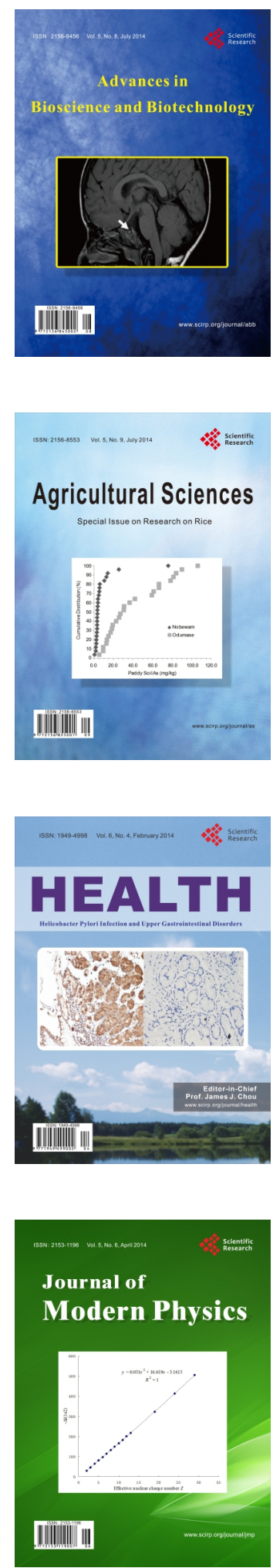
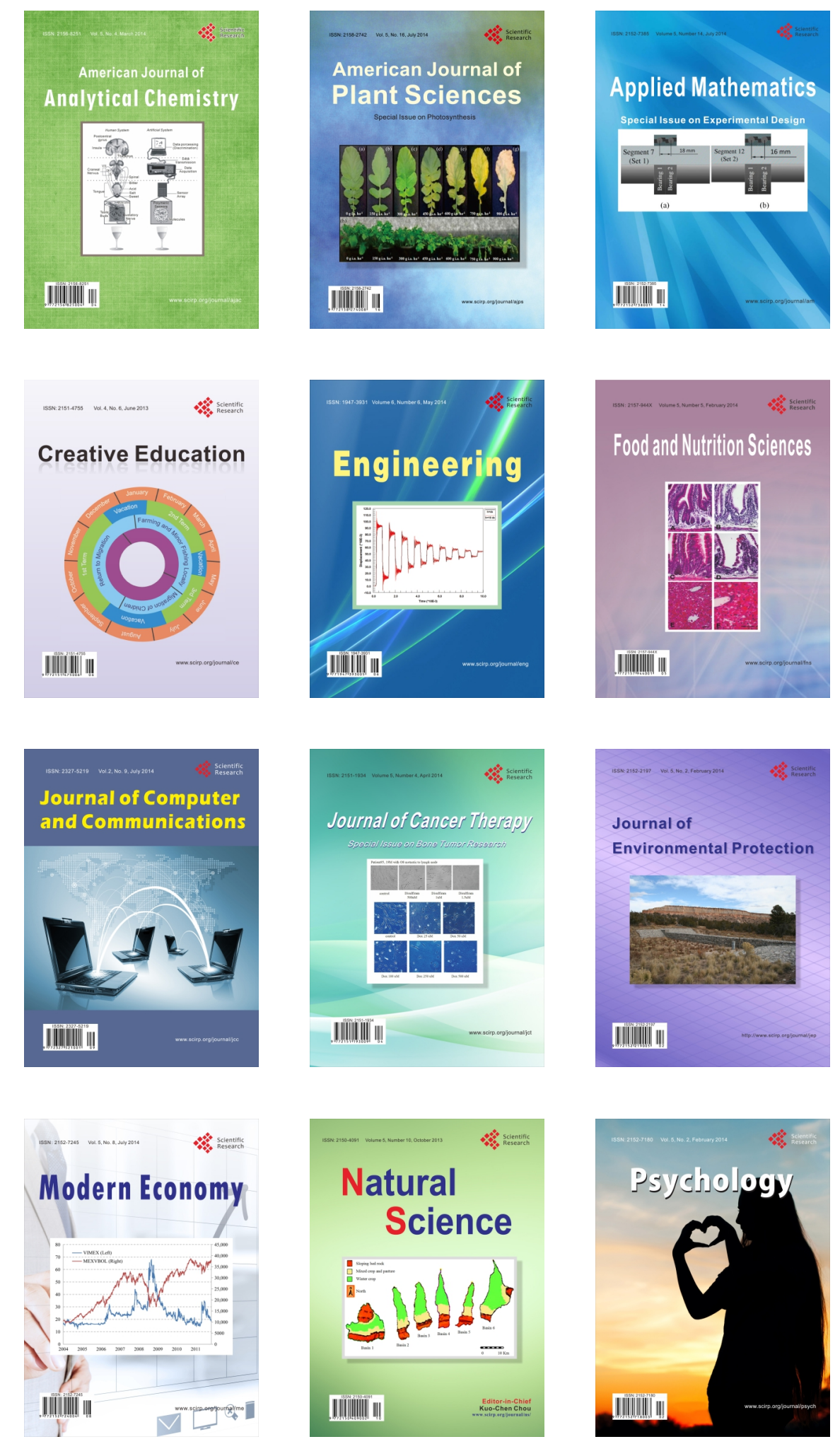